\title{
Economic optimum big sagebrush control for increasing crested wheatgrass production
}

\author{
JOHN A. TANAKA AND JOHN P. WORKMAN
}

\begin{abstract}
An approach was developed for estimating the economic optimum rate of initial overstory kill for increasing seasonal forage availability. The model was formulated using: (1) \& biological production function relating understory production to initial kill percentage, (2) a derived demand function for seasonal forage value, and (3) a cost of overstory kill function for each control method. The specific optimum solution will vary with the situation; however, the general model may be applied to any ranching situation where understory forage production is constrained by undesirable overstory vegetation. The model was illustrated using the big sagebrush-crested wheatgrass vegetation type on a Utah cow-calf-yearling operation with preseribed burning, 2,4-D spraying, and tebuthiuron application as control methods. For the ranch analyzed, a big sagebrush kill rate between 92 and $100 \%$ is optimal depending on the derived demand and cost-of-kill functions used. Kill rates that differ from the optimum caused significant opportunity costs to be incurred.
\end{abstract}

Key Words: optimization, overstory control, understory release, economics

Investments in control of undesirable vegetation to increase forage production have the potential to increase red meat production, ranch profits, and other benefits to society such as reduced soil erosion. To achieve such benefits requires careful planning, implementation, and monitoring of vegetation control projects. The purpose of this study was to investigate and develop usable mathematical and tabular approaches for estimating the optimum (profit maximizing) rate of initial overstory kill for increasing seasonal forage availability on a given ranch. The focus is how the ranch should approach biological and economic decisions for the alleviation of an identified seasonal forage bottleneck in a yearlong ranch operation.

The biological relationship between overstory dominance and understory production has been documented for many vegetation types (Ffolliott and Clary 1982, Bartlett and Betters 1983). The analytical approach examined in this study was illustrated using big sagebrush (Artemisia tridentata Nutt.) -crested wheatgrass (Agropyron desertorum (Fisch. ex Link) Schult., A. cristatum (L.) Gaertn.) vegetation relationships in a Utah cow-calf-yearling operation. The rate of big sagebrush re-establishment on a specific site depends on the percentage initial kill, subsequent grazing management, ecological adaptation of sagebrush to the site, and reinvasion of sagebrush from outside the treatment area (Pechanec et al. 1965, Hull and Klomp 1966, Johnson and Payne 1968, Winward 1983). Benefits from brush reduction include improved range condition, increased forage and livestock production, ease of working cattle, increased feed for wildlife, and improved watershed conditions (McDaniel 1980). Multiple use management may dictate that not all big sagebrush be removed. However, Evans et al. (1979) examined the biological relationships and recommended

\footnotetext{
Authors are assistant professor, Agricultural and Resource Economics Department, Oregon State University, Corvallis 97331; and professor Range Science Department, UMC 52, Utah State University, Logan 84322. At the time of the research, the senior author was research assistant, Range Science Department, Utah State University.

Published with the approval of the Director, Utah Agricultural Experiment Station, as Journal Paper No. 3352.

Manuscript accepted 14 October 1987.
}

complete reduction on some areas and no treatment on adjacent areas. The approach described in this paper should be applicable in any vegetation type exhibiting an undesirable overstory-desirable understory relationship and for any ranch operating year-long subject to seasonal forage shortages.

\section{Methods}

\section{Production Function}

The response of established crested wheatgrass to big sagebrush reduction has been studied on both basin big sagebrush (A.t. subsp. tridentata Nutt.) and Wyoming big sagebrush (A.t. subsp. wyomingensis Beetle) sites in southern Idaho (Hull and Klomp 1974). Big sagebrush was reduced $0,50,75$, and $100 \%$ from initial canopy covers of 33.7 and $11.4 \%$ at the basin and Wyoming sites, respectively, with initial densities of about 20 plants per $100 \mathrm{ft}^{2}$ $\left(9.29 \mathrm{~m}^{2}\right)$. Burning, 2,4-D, and hand grubbing were used at each kill level in 2 blocks at each site (near Twin Falls and Holbrook, Idaho). Crested wheatgrass response was not significantly affected by treatment method. The important factor was the amount of big sagebrush removed. Killing the last $25 \%$ of the big sagebrush stand resulted in 135 and $98 \%$ more grass than killing the first $75 \%$ on the basin and Wyoming big sagebrush sites, respectively (Hull and Klomp 1974).

Data from the basin big sagebrush and Wyoming big sagebrush sites were analyzed separately to estimate 2 specific production functions. Multiple regression was used to estimate the production function using the computer econometric program "SHAZAM" (White 1978). A 2-year deferment (treatment year and year following) was assumed and the function was estimated using data from 1967 to 1970 , inclusive. Crop year precipitation and crested wheatgrass stand age were used in the estimation procedure as suggested by Sneva and Britton (1983) and White (1985). The production function was based on the assumption that any increase in forage from an overstory treatment remained constant from the first year of grazing until the end of the project life. Maximum project life was defined as the time interval required for big sagebrush canopy cover on the treated area to equal its pretreatment level.

The Goodness-of-Fit Test $(\alpha=0.05)$ and the coefficient of skewness test were used to assess normality as described by Kmenta (1971). If these 2 tests disagreed, the scatter plot of residuals was examined and a judgment made about the effects of any departure from a normal distribution on model estimation and interpretation. The test statistic, $\hat{\lambda}$, as described by Kmenta (1971) was used to test for homoskedasticity using the 4 sample points. The 4 years of data used to estimate the function were tested for autocorrelation by use of the Durbin-Watson test as described by Kmenta (1971). Degree of multicollinearity was determined by (1) an examination of the correlation matrix of coefficients and (2) by the " $R^{2}$-delete" method (Kmenta 1971).

The overall production function significance was tested with the F-test $(\alpha=0.05)$ and individual coefficients with the Student's $t$-test. The formal criteria for including a variable in the final model were: (1) whether the $t$-value for a coefficient was statistically significant or (2) whether the computed $t$-value was greater than one when the computed $F$-value was statistically significant in order to maximize the value of the adjusted $R^{2}$ (Kmenta 1971). Statistically significant environmental and time variables were set 
at their respective long-term average values for the area and added to the regression constant. The resulting deterministic production function related initial big sagebrush kill levels to "typical" or average crested wheatgrass production.

Production function values were adjusted for both desired utilization rate and availability of forage to livestock. The availability function was based on observations by Hull and Klomp (1974) and assumed to be linear between 40 and $90 \%$ as big sagebrush canopy cover varied from 34 to $0 \%$. The last $10 \%$ unavailable was assumed to be due to the inability of a method to remove all sagebrush skeletons so that some obstacles to forage availability remained. The optimum utilization rate of crested wheatgrass by grazing herbivores was set at $65 \%$ (Torell 1984).

\section{Derived Demand for Spring Forage}

The "typical" Utah ranch operation data set was analyzed by the COPLAN linear programming (LP) model (Evans 1978) to identify the value of additional crested wheatgrass forage obtained by reducing big sagebrush canopy cover on a given ranch with a given mix of forage sources. The "typical" Utah ranch with 206 brood cows operates as a cow-calf-yearling operation with a $15 \%$ replacement rate, a 24:1 cows bred:bull ratio, and an $82 \%$ calf crop based on January 1 inventory of brood cows (Dickie and Workman 1985). Feed sources include native foothill range, crested wheatgrass on treated established stands, meadows, crop aftermath, and forage available through Bureau of Land Management permits, U.S. Forest Service permits, and private leases. Additional spring forage has been identified as a need and one option for providing it was to reduce big sagebrush to increase early maturing grasses. Demand for this additional forage is derived from the underlying production process (hence the term derived demand). Demand is defined in economics as the amount of a good or service that a buyer is willing and able to buy at any given price, all else equal. Derived demand for additional early spring forage represents the amount that a given ranch is willing and able to spend for that forage, all else equal (e.g., variable costs of production, livestock prices, other forage sources, livestock enterprise).

Each forage production level of treated crested wheatgrass pasture was used in COPLAN with all other forage sources constant (except untreated hectares of crested wheatgrass were reduced by the size of the treated stand). Each run resulted in a different shadow price $(\$ /$ ha) for crested wheatgrass forage. The crested wheatgrass forage shadow price represented the net value to the ranch of 1 additional acre of crested wheatgrass. This shadow price was converted to a $\$ / \mathrm{kg}$ value by dividing by the corresponding production per ha value. A derived demand function (relating price of crested wheatgrass forage to usable forage produced) for additional crested wheatgrass production was estimated from the results and used in the optimal kill models.

Valuation of additional forage was based on the premise that no 2 ranches are alike. The fixed cost per $\mathrm{kg}$ of forage produced was between $\$ 0.003 / \mathrm{kg}$ and $0.006 / \mathrm{kg}$ for the "typical" Utah ranch studied by Capps and Workman (1982). A rounded average value of $\$ 0.0045 / \mathrm{kg}$ was subtracted from the short-term function to yield a long-term derived demand function. Short-term was based on the time frame where some of the costs of production do not change with the level of production and as such do not enter into the optimization model. In the long-term, however, the ranch must account for these costs in order to stay in business. The long-term derived demand function was used to show this effect on profits.

\section{Cost-of-Kill Functions}

Cost-of-kill functions were designed to predict cost per hectare for any given level of initial big sagebrush kill in a wide geographic area. On-the-ground average costs for prescribed burning, 2,4-D spraying, and tebuthiuron application were obtained from interviews conducted with range conservationists with the Bureau of Land Management (Salt Lake City, Utah, and Boise, Idaho), U.S. Forest Service (Malad, Idaho), and Soil Conservation Service
(Tremonton, Logan, and Price, Utah) on specific big sagebrush reduction projects conducted between 1980 and 1984. Data were collected for initial kill percentage, project size, actual investment (i.e., total and per hectare project costs), big sagebrush subspecies, type of treatment, pretreatment big sagebrush canopy cover, and estimated precipitation zone. The latter information was used to identify projects with similar conditions to increase the homogeneity of the data set used.

Additional control efforts were always required to achieve $100 \%$ kill of a stand of big sagebrush. No single method was completely effective. It was assumed that each of the 3 basic methods was used at its most efficient level (giving the highest obtainable kill) and then the additional follow-up cost for complete reduction was added to obtain the cost for $100 \%$ kill. A \$10/ ha charge was added to the highest observed percent kill level cost/ha to estimate costs of complete kill based on values published in the literature for individual plant burning or hand grubbing (Arnold et al. 1964).

\section{Optimization Procedure}

The objective function for the optimum kill model was equivalent to the formula commonly used in present net worth (PNW) analysis of range improvement practices (Workman 1981). The usable forage per hectare was multiplied by the shadow price appropriate for the initial kill level to determine the annual net benefit of the project to the specific ranch. Each annual net benefit was discounted to the present and summed to obtain the present net value of project benefits per hectare. Project costs (initial per hectare investment) for each particular combination of initial kill and project size were estimated and subtracted from the project benefits to estimate PNW. The optimization model was used to determine the profit maximizing initial kill level.

PNW was then calculated in a "typical ranch" context, based on the estimated functions. The basin and Wyoming big sagebrushcrested wheatgrass production functions were each combined with short- and long-term annual net value and cost of kill functions for prescribed burning, 2,4-D spraying, and tebuthiuron application. The long-term annual net value included the fixed costs allocated to the project on a per hectare basis (Torell 1984). The discount rate of $7 \%$ used in the analysis consisted of a real rate of $4 \%$ and a risk factor of $3 \%$ (Torell 1984).

The tabular approach was used to find a quasi-optimal solution using an electronic spreadsheet (Lotus 1-2-3 ${ }^{\mathrm{TM}}$ ) following tabular solutions illustrated by Workman (1986). Annual usable forage values were multiplied by the short-term crested wheatgrass value function with the resulting annual net benefit values. Present net benefits (PNB) for each initial kill level were then computed as the present value of project benefits minus present value of benefits without the project. Present net worth estimates were calculated for each initial kill alternative by subtracting initial investment from PNB.

\section{Results and Discussion}

The model was developed under the premise that the spring grazing season constrains the year-long grazing cycle and that the shortage of early spring forage had resulted from the decline in an existing forage stand. Once the need for additional forage was identified, the manager must compare the value of additional forage to the costs of obtaining that additional forage from an overstory reduction project.

\section{Theoretical Model}

The objective function is to maximize PNW from additional crested wheatgrass forage over the life of the control project. The production function, cost-of-kill function, and the value of additional crested wheatgrass function are combined to form the optimization model. The model assumes (1) constant deferment periods among treatment intensities, (2) a given grazing management strategy, (3) that the treatment method does not affect biolog- 
ical responses except through the level of initial kill, and (4) that the crested wheatgrass stand is subject to big sagebrush re-establishment.

The optimization model is stated as

$$
\underset{X, \bar{S}}{\operatorname{Max}} \mathbf{N}(1)=\underset{t=t_{0}}{\bar{S}} \mathbf{P}\left[\mathrm{U} A Y \mathbf{c}^{-\rho t}-K\right.
$$

where

$$
\begin{aligned}
& N(1)=\text { Present net worth of a single treatment period per ha } \\
& \text { (S/ha), } \\
& \mathbf{Y}=\text { Average crested wheatgrass production function for a } \\
& \text { given } S(\mathrm{~kg} / \mathrm{ha}) \text {, } \\
& \mathbf{X}=\text { Initial kill level of big sagebrush (\% canopy reduction), } \\
& \mathbf{K}=\text { Cost of initial kill function }(\mathbf{S} / \mathrm{ha}) \text {, } \\
& P=\text { Derived demand function for crested wheatgrass forage } \\
& \text { (\$/ha), } \\
& \mathrm{U}=\text { Utilization rate (\%), } \\
& A=\text { Crested wheatgrass availability function (\%), } \\
& t=\text { Stand age since last treatment (integer years), } \\
& \underline{t_{0}}=\text { First post-deferment grazing period, } \\
& S=\text { Maximum project life for a given initial kill level, } \\
& \rho=\text { The discount rate. }
\end{aligned}
$$

In addition, the problem is defined such that initial big sagebrush canopy cover is not more than $34 \%$ and the desired AUM increase, season of use, livestock class, and grazing system are specified. Eq. (1) represents an unconstrained maximization problem where the objective is to maximize the PNW of a project with respect to the choice of $\mathrm{X}$ and $\bar{S}$. Note that in the deterministic model given here, once $\mathrm{X}$ is selected, $\bar{S}$ automatically follows by assumption. The first-order conditions for optimization specify that at the optimum point (1) the change in the discounted accumulated annual net returns must equal the change in the cost of the kill function when both are evaluated at $X^{*}$ (the solution value of $X$ ) and (2) that at $\bar{S}^{*}$-the maximum project life associated with $X^{*}$-no further gains can be made by extending project life another year.

\section{Empirical Model Estimation}

Coefficients for each function are given in Table 1 . The overall equations were significant based on the F-test. The production functions shown in Figure 1 were set at average year values. Production of crested wheatgrass was multiplied by utilization and availability factors to convert it to usable forage produced. The resulting equation was:

$$
\begin{aligned}
\Phi= & U A \mathrm{Y}=0.65(0.4+0.005 \mathrm{X}) \mathrm{Y} \\
= & (0.26+0.00325 \mathrm{X}) \mathrm{Y} \\
\text { where } \quad \Phi= & \text { Usable crested wheatgrass forage }(\mathrm{kg} / \mathrm{ha}), \\
& \text { and all other variables are defined as in Eq. } 1 .
\end{aligned}
$$

The forage valuation approach allowed COPLAN to select the best available forage alternative (e.g., native foothill range, untreated crested wheatgrass stands, leases and permits) given a specified level of treated sagebrush in an existing crested wheatgrass stand. The valuation method also emphasized the economic principle that when an input is in oversupply (i.e., nonconstraining), an additional unit has no value to the ranch. The short-term

Table 1. Production, derived dernand, and cost-of-kjli function coefileients with eatimated t-values in parentheaces. Adjueded $R^{2}$ and F-values for each equation are shown below the coefincients.

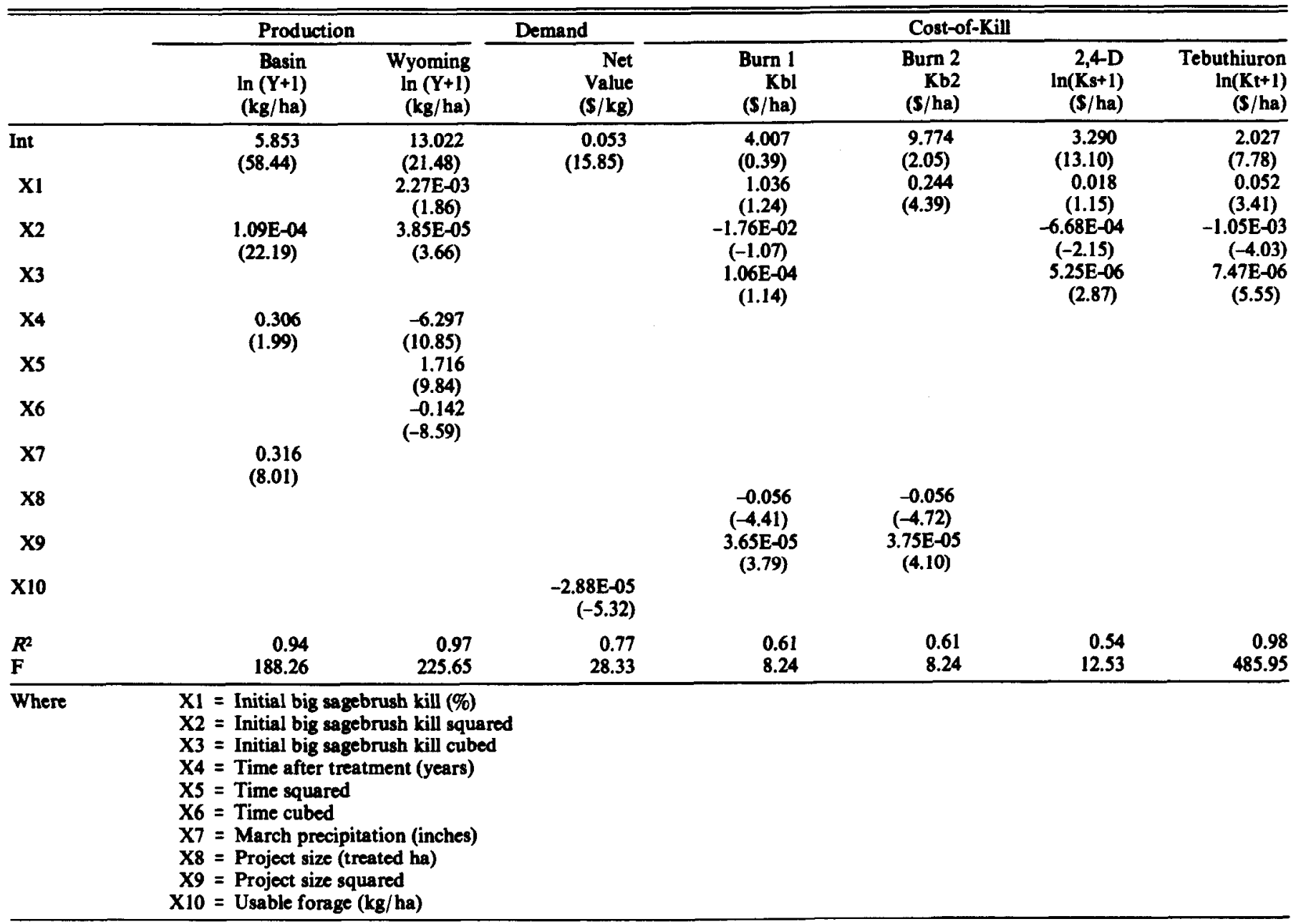




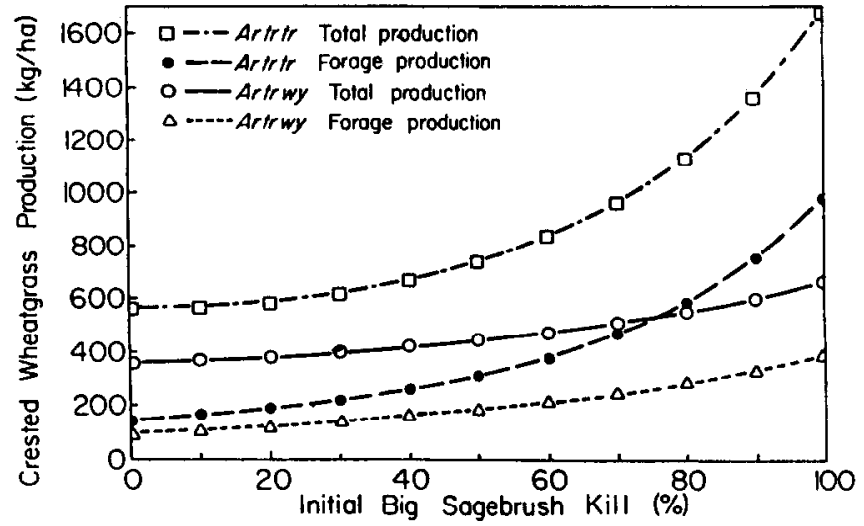

Fig. 1. Crested wheatgrass production and forage yields as functions of percentage ktll of 2 big sagebrush subspecies.

derived demand coefficients are given in Table 1 . This procedure understates the total value of the forage to the ranch by the area under the derived demand curve and above the annual value selected (i.e., consumer surplus). In essence, all of the forage produced is valued at the marginal value. Once the usable forage level is determined, a forage price is specified. As with any deterministic model, use of LP can only approximate real world situations.

The costs-of-kill function coefficients are given in Table 1 and graphed in Figure 2. Of the estimated functions, only the prescribed burning ( $\mathrm{Kb2}$ ) cost was linearly related to initial kill level and all other functions were sigmoid (Fig. 2). Of the nonlinear

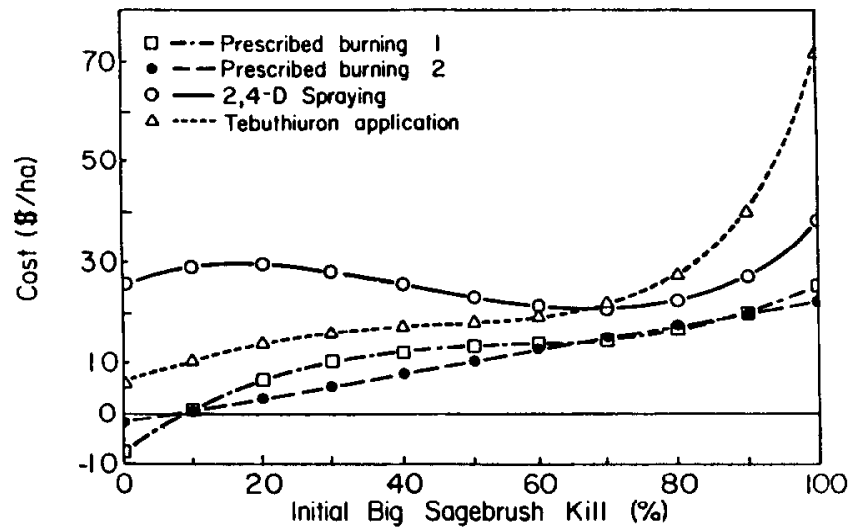

Fig. 2. Big sagebrush control costs as functions of percentage kill, 4 control methods.

functions, the 2,4-D (Ks) function did not appear to "fit" preconceived ideas of functional shape-i.e., zero \% kill had a significant cost and costs at low kill levels were greater than at higher kill levels. The prescribed burning (Kbl) and tebuthiuron application $(\mathrm{Kt})$ cost of kill functions more accurately depicted the expected relationship. Project size (i.e., treated ha) was retained only for the prescribed burning function. No such effect was found for 2,4-D, and the effect was deemed insignificant for tebuthiuron projects. The cost-of-kill approach employed in this study considers the type of method to use and how intensively that method is used.

The annual net retum function is obtained by multiplying either

Table 2. Solution to the optimal basin big sagebruab kill level uding the short-term dorived demand and tebuthiuron cost of kill function.

\begin{tabular}{|c|c|c|c|c|c|c|}
\hline $\begin{array}{l}\text { Initial kill } \\
(\%)\end{array}$ & $\begin{array}{c}\text { Annual usable } \\
\text { forage } \\
\text { (kg/ha) }\end{array}$ & $\begin{array}{c}\text { Annual net } \\
\text { return } \\
(\$ / h a)\end{array}$ & $\begin{array}{c}\text { Project } \\
\text { life } \\
(y r)\end{array}$ & $\begin{array}{c}\text { PNB } \\
\text { (S/ha) }\end{array}$ & $\begin{array}{c}\text { Initial } \\
\text { cost } \\
(\$ / h a)\end{array}$ & $\begin{array}{l}\text { PNW } \\
\text { (\$/ha) }\end{array}$ \\
\hline $\begin{array}{r}0 \\
10 \\
20 \\
30 \\
40 \\
50 \\
60 \\
70 \\
80 \\
90 \\
100\end{array}$ & $\begin{array}{l}146 \\
166 \\
191 \\
222 \\
261 \\
312 \\
379 \\
468 \\
589 \\
753 \\
982\end{array}$ & $\begin{array}{r}7.15 \\
8.03 \\
9.09 \\
10.36 \\
11.91 \\
13.77 \\
16.00 \\
18.56 \\
21.28 \\
23.66 \\
24.37\end{array}$ & $\begin{array}{r}0 \\
5 \\
6 \\
7 \\
8 \\
10 \\
12 \\
14 \\
16 \\
18 \\
25\end{array}$ & $\begin{array}{r}-13.83 \\
-11.02 \\
-6.39 \\
0.49 \\
10.14 \\
26.52 \\
48.20 \\
75.28 \\
106.48 \\
136.83 \\
170.82\end{array}$ & $\begin{array}{r}6.59 \\
10.60 \\
14.04 \\
16.31 \\
17.50 \\
18.18 \\
19.19 \\
21.57 \\
27.02 \\
39.39 \\
69.72\end{array}$ & $\begin{array}{r}-20.42 \\
-21.62 \\
-20.43 \\
-15.82 \\
-7.35 \\
8.34 \\
29.00 \\
53.71 \\
79.46 \\
97.44 \\
101.10\end{array}$ \\
\hline $\begin{array}{r}80 \\
81 \\
82 \\
83 \\
84 \\
85 \\
86 \\
87 \\
88 \\
89 \\
90 \\
91 \\
92 \\
93 \\
94 \\
95 \\
96 \\
97 \\
98 \\
99 \\
100\end{array}$ & $\begin{array}{l}589 \\
603 \\
618 \\
633 \\
648 \\
664 \\
681 \\
698 \\
716 \\
734 \\
753 \\
773 \\
793 \\
814 \\
836 \\
858 \\
881 \\
905 \\
930 \\
955 \\
982\end{array}$ & $\begin{array}{l}21.28 \\
21.55 \\
21.81 \\
22.07 \\
22.32 \\
22.57 \\
22.81 \\
23.04 \\
23.26 \\
23.46 \\
23.66 \\
23.84 \\
24.00 \\
24.14 \\
24.26 \\
24.36 \\
24.43 \\
24.47 \\
24.47 \\
24.44 \\
24.37\end{array}$ & $\begin{array}{l}16 \\
16 \\
16 \\
16 \\
16 \\
16 \\
17 \\
17 \\
17 \\
17 \\
18 \\
18 \\
19 \\
19 \\
20 \\
20 \\
21 \\
22 \\
23 \\
24 \\
25\end{array}$ & $\begin{array}{l}106.48 \\
108.75 \\
110.99 \\
113.19 \\
115.34 \\
117.44 \\
124.43 \\
126.46 \\
128.39 \\
130.23 \\
136.83 \\
138.46 \\
144.60 \\
145.94 \\
151.49 \\
152.43 \\
157.27 \\
161.58 \\
165.30 \\
168.39 \\
170.82\end{array}$ & $\begin{array}{l}27.02 \\
27.85 \\
28.74 \\
29.72 \\
30.78 \\
31.93 \\
33.17 \\
34.53 \\
36.02 \\
37.63 \\
39.39 \\
41.31 \\
43.42 \\
45.72 \\
48.24 \\
51.02 \\
54.06 \\
57.42 \\
61.11 \\
65.20 \\
69.72\end{array}$ & $\begin{array}{r}79.46 \\
80.90 \\
82.24 \\
83.47 \\
84.56 \\
85.51 \\
91.25 \\
91.92 \\
92.38 \\
92.60 \\
97.44 \\
97.15 \\
101.18 \\
100.22 \\
103.25 \\
101.41 \\
103.21 \\
104.16 \\
104.18 \\
103.19 \\
101.10\end{array}$ \\
\hline
\end{tabular}


the short-term or long-term derived demand function by the usable forage function (Eq. 2) such that:

$$
\begin{aligned}
D_{2} & =P U A Y=P \Phi \\
& =(0.053-0.000028 \Phi) \Phi \\
& =0.053 \Phi-0.0000228 \Phi^{2}
\end{aligned}
$$

and similarly

$$
D_{1}=0.048 \Phi 0.0000228 \Phi^{2}
$$

where

$$
\begin{aligned}
D_{8}= & \text { Short-term annual net return function ( } \$ / \text { ha), } \\
D_{1}= & \text { Long-term annual net return function ( } \$ / \text { ha), } \\
& \text { and } P, U, A, Y, \Phi, \text { and } X \text { as defined in Eqs. (1) and (2). }
\end{aligned}
$$

Equations 3 and 4 provide the components of the optimization model established in Eq. 1 over which the ranch can exercise some control in its decision-making process. Once an initial kill level is determined, the value of $D_{1}$ and $D_{1}$ are also determined for the relevant project life. The difference in the 2 equation intercept terms is due to the fixed cost allocation in the long-term function.

Any of the cost of kill functions can be combined with Eq. 3 or Eq. 4 to estimate an optimal target kill rate. The discounting factor is the final model component. This factor requires 3 variables-the discount rate $(\rho)$, deferment length $\left(t_{0}\right)$, and maximum project life $(\bar{S})$. The total mathematical optimization model is written using the basin big sagebrush production function, short-term derived demand function, and tebuthiuron cost-of-kill function as:

$$
\begin{aligned}
\mathrm{N}(1)= & \bar{s} \\
\mathrm{t}_{\mathrm{t}=\mathrm{t}_{0}} & \\
& -\left(\exp (2.027+0.053 \Phi 0.0000288 \Phi) \mathrm{e}^{-0.07 t}\right. \\
& \left.+0.00000747 \mathrm{X}^{3}\right)-1
\end{aligned}
$$

The last part of this equation is the tebuthiuron cost-of-kill function solved for $\mathrm{Kt}$ (see Table 1). The first order condition for a maximum of this model is not easily solvable to find the profit maximizing level of initial kill ( $\mathrm{X}^{*}$ ).

\section{Utah Application}

A convex (bowed downwards) production function as illustrated in Figure 1 has been observed in numerous vegetation types ranging from semidesert to forest. Given a constant cost of kill and constant forage value as normally assumed, a convex production function always implies an optimal solution with an overstory kill of either zero or $100 \%$. Addition of the derived demand and cost of kill functions prevents this automatic (and overly simplified) conclusion.
The tabular solution to Eq. 5 is shown in Table 2 for given initial kill rates. The results shown in Table 2 indicate that the optimal (profit maximizing) kill level lies between 80 and $100 \%$. The lower portion of Table 2 shows the PNW estimates for each integer kill level over this $20 \%$ range. For this procedure the optimal target kill rate is about $98 \%$, which is expected to return $\$ 104.18$ per ha over the 23-year project life.

The opportunity cost associated with a non-optimal target kill rate may be substantial. Investments in overstory kill resulting in a non-optimal kill level would result in lower profits than shown in Table 2. For example, if a decision is made to kill only $50 \%$ of the basin big sagebrush in an area (perhaps to produce forage for livestock and to maintain cover for wildlife) rather than the optimum kill rate, the ranch will incur an opportunity cost of about $\$ 104 /$ ha and will receive only about $\$ 8 / \mathrm{ha}$, a foregone net benefit of about $\$ 96 /$ ha. To produce the same amount of additional forage, it would be necessary to treat more than 3 times as much land. In addition, the treated land would not result in a profit maximizing solution.

All other combinations of big sagebrush subspecies, derived demand, and kill methods were analyzed (Table 3). In all cases tested, results indicate the optimal kill rate lies between 92 and $100 \%$. The highest PNW estimates were for burning, followed closely by 2,4-D spraying. All optimal initial kill levels shown in Table 3 are sensitive to the utilization rate and discount rate assumptions used in their derivations. The tebuthiuron results illustrate 2 economic points: (1) the lower long-term forage value (due to a fixed cost allocation) caused the optimal initial kill value to decline and (2) the lower productivity (and smaller response) of the Wyoming big sagebrush site resulted in lower PNW estimates. The prescribed burning results illustrate a third point: when project size increased, the cost of kill function was shifted vertically downward such that at a given initial kill level the curve slopes were about equal. Results shown in Table 3 indicate that this shift did not affect the optimal kill rate but did increase project PNW.

The points illustrated by Table 3 agree with general economic theory: (1) as the price of an output decreases, less of the variable input should be used to produce it; (2) invest in the best opportunities (more productive sites) first; (3) corner solutions (i.e., 0 or $100 \%$ kill) such as found with 2,4-D spraying of Wyoming big sagebrush are relatively insensitive to price changes; and (4) that the optimal solution depends on the slope of the functions rather than their absolute values. Because of the discrete time aspect of the problem, PNW values tended to change discontinously as seen

Table 3. Summary of optimal target kill rates for combinations of big sagebrush subspecies production, derived demand, and cost of kill functions for the STP static model.

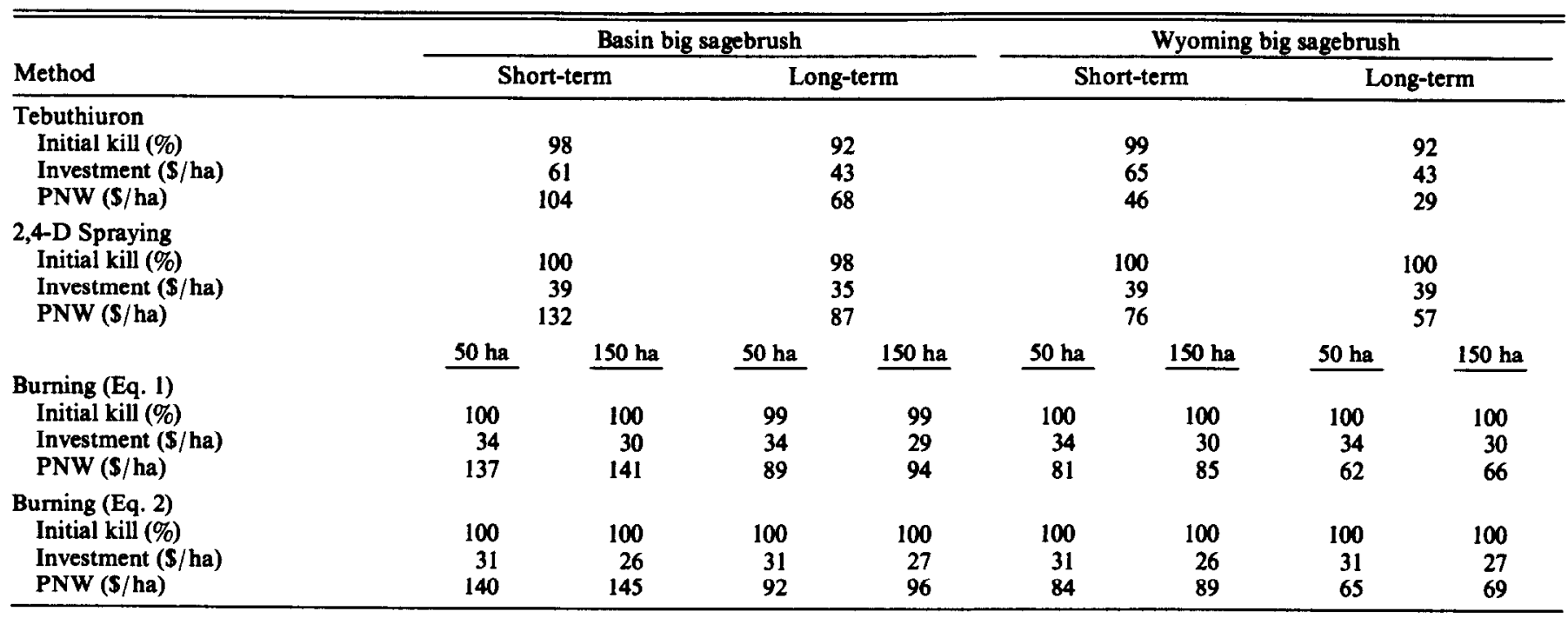


in the last column of Table 2.

An assumption used in developing the cost-of-kill functions was to add \$10/ha to the cost of producing the highest kill rate for each treatment. Although this assumption was not critical to the analysis, it was added to make the situation somewhat more realistic. It was felt that to achieve $100 \%$ kill would require additional investments (i.e., it could not be done for free). As with any assumption, its value or direction could be changed and the analysis redone to account for this. In fact, this should be done when applying the model to any actual ranch situation.

From an economic efficiency or profit view for this particular ranch, an overstory kill project should be implemented to achieve the highest possible initial kill level. On better (more productive) sites, the goal may not be complete control since the same level of PNW could be achieved for less investment. Nevertheless, kill rates in excess of $90 \%$ require skillful application of the method under nearly ideal conditions. A threshold initial kill level likely exists for each method (where PNW goes from negative to positive as higher initial kill levels are achieved), as illustrated in Table 2 between 40 and $50 \%$ initial kill. The extreme solution would be when this transition occurred at either 0 to $100 \%$ kill.

\section{Conclusions}

The analytical process described will help identify and define components necessary for an optimization process and for ranch planning. However, more information is needed about long-term biological production relationships over a wide variety of conditions in different vegetation types, e.g., the effects of overstory reestablishment and grazing management on the time path of forage production following overstory kill. More accurate information will increase the feasibility of dynamic (time effects considered) model formulation for on-the-ground management decisions. Cost-of-kill relationships for each method must also be more accurately defined. Ideally, costs to achieve a target kill rate should be predictable for a specific area, taking into account differences in costs due to topography, rockiness, and stand density. The resulting models would be more realistic in terms of economic and biological relationships.

The analytical models developed in this study demonstrate the potential rewards of well-planned and well-managed forage stands that are susceptible to undesirable overstory re-establishment. The model provides estimates of project PNW, the optimal investment level, and required project size. The 2 estimable functions (production and cost of kill) can be developed independent of information of a specific ranch required in the planning process. However, the optimization procedure requires that the total ranch effects of a change in seasonal forage availability be identified. The year-long operation of a ranch must be identified and described quantitatively, both biologically and economically. This information is required for ranch planning in general.

Although ranchers may not be prepared to use a linear programming model to generate forage shadow prices, the method is available and useful. Some producers currently use LP while others have access to the COPLAN model through the SCS and private consultants. It may also be feasible to substitute other simpler forage valuation techniques with the recognition that there will be a loss in accuracy. No matter what valuation method is used, it must use feasible forage alternatives for the forage bottleneck season and value that forage as such.

The model can be implemented with existing data bases and ranch information. This is not to suggest that the information is easily obtained and analyzed, rather that is obtainable in a reasonable time frame on a specific ranch basis. The move from a static (i.e., time is not a factor) to a dynamic production function represents a biological step toward realism, while the move to an optimal control model (as described in Kamien and Schwartz 1982) is the next economic step. The "no data" problem discussed by Torell (1984), Martin (1972), and Burt (1972) in long-term dynamic optimization models does not appear to be a significant problem with the developed model. Enough research results are available to reasonably estimate static production functions. Data for estimating dynamic production functions are more difficult to obtain by standard rangeland inventory procedures except in short-lived projects such as those described by Ethridge et al. (1984) and economically analyzed by Torell and McDaniel (1986). Otherwise, long-term biological production data sets must be provided through a simulation model.

The developed optimization model is obviously less realistic than the dynamic models described by Cotner (1963), Burt (1971), and Torell (1984). It does, however, have the advantage of reasonable data requirements while at the same time capturing many of the complexities of the optimization problem. As Burt (1982) stated, "the primary objective in all modeling is to capture the essential aspects ... yet keep the model as simple as possible." The developed model appears to hold promise for fulfilling this requirement in applied planning. This agrees with Martin's (1972) conclusion that the range profession has not yet provided adequate data bases for the empirical solution of dynamic optimization models. As pointed out by Burt (1972), one benefit of economic modeling is to define the requisite relationships for analysis. One goal of this project was to further develop these relationships.

\section{Literature Cited}

Arnold, J.F., D.A. Jameson, and E.H. Reid. 1964. The pinyon-juniper type of Arizona: Effects of grazing, fire, and tree control. USDA-FS Prod. Res. Rep. 84.

Bartlett, E.T., and D.R. Betters. (eds.). 1983. Overstory-understory relationships in western forests. West. Reg. Res. Pub. 1.

Burt, O.R. 1971. A dynamic economic model of pasture and range improvements. Amer. J. Agr. Econ. 53:197-205.

Burt, O.R. 1972. More sophisticated tools for less important problems: The history of range improvement research: Reply. Amer. J. Agr. Econ. 54:134-135.

Burt, O.R. 1982. Dynamic programming: Has its day arrived? West. J. Agr. Econ. 7:381-393.

Capps, T.L., and J.P. Workman. 1982. Management, productivity, and economic profiles of 2 sizes of Utah cattle ranches. Utah Agr. Exp. Sta. Res. Rep. 69.

Cotner, M.L. 1963. Optimum timing of long-term resource improvements. J. Farm Econ. 45:732-748.

Dickie, A., and J.P. Workman. 1985. Value of seasonal forage to Utah cattle ranches. Abstract of papers of 38th Annual Meeting, Society for Range Management, February 14, 1985, Salt Lake City, Utah.

Ethridge, D.E., B.E. Dahl, and R.E. Sosebee. 1984. Economic evaluation of chemical mesquite control using 2,4,5-T. J. Range Manage. 37:152-156.

Evans, G.R. 1978. Systems approach for land resource analysis and planning of limited renewable natural resources. J. Anim. Sci. 46:819-822.

Evans, R.A., J.A. Young, and R.E. Eckert, Jr. 1979. Use of herbicides as a management tool, p. 110-116. In: The sagebrush ecosystem: a symposium, 1978, Utah State Univ., Logan.

Ffolliott, P.F., and W.P. Clary. 1982. Understory-overstory vegetation relationships: an annotated bibliography. Inter. Forest and Range. Exp. Sta. Gen. Tech. Rep. INT-136.

Hull, A.C., Jr., and G.J. Klomp. 1966. Longevity of crested wheatgrass in the sagebrush-grass type in southern Idaho. J. Range Manage. 19:5-11.

Hull, A.C., Jr., and G.J. Klomp. 1974. Yield of crested wheatgrass under four densities of big sagebrush in southern Idaho. USDA-ARS Tech. Bull. 1483.

Johnson, R.J., and G.F. Payne. 1968. Sagebrush reinvasion as affected by some environmental influences. J. Range Manage. 21:209-212.

Kamien, M.L., and N.L. Schwartz. 1981. Dynamic optimization: the calculus of variations and optimal control. Elsevier North Holland, Inc., New York.

Kmenta, J. 1971. Elements of econometrics. Macmillan Publishing Co., Inc., New York.

Martin, W.E. 1972. More sophisticated tools for less important problems: the history of range improvement research: a comment. Amer. J. Agr. Econ. 54:132-134.

McDaniel, K.C.1980. Brush and weed control on New Mexico ranges. NM Coop. Ext. Serv. Guide B-806. 
Pechanec, J.F., A.P. Plummer, J.H. Robertion, and A.C. Hull, Jr. 1965. Sagebrush control on rangelands. USDA Agr. Handbook 277.

Sneva, F., and C.M. Britton. 1983. Adjusting and forecasting herbage yields in the intermountain big sagebrush region of the Steppe Province. Oregon Agr. Exp. Sta. Bull. 659.

Torell, L.A. 1984. Economic optimum stocking rates and treatment schedule for crested wheatgrass stands. Ph.D. Thesis, Utah State Univ., Logan, Utah.

Torell, L.A., and K.C. MeDaniel. 1986. Optimal timing of investments to control honey mesquite. J. Range Manage. 39:378-382.

White, K.J. 1978. A general computer prrgram for econometric methodsSHAZAM. Econometrica 46:239-240.
White, L.M. 1985. Stand age, precipitation, and temperature effects on forage yield. J. Range Manage. 38:39-43.

Winward, A.H. 1983. Using sagebrush ecology in wildland management. In: K.L. Johnson (ed), Proc. First Utah Shrub Ecology Workshop, Utah State Univ., Logan.

Workman, J.P. 1981. Disagreement among investment criteria-a solution to the problem. J. Range Manage. 34:319-324.

Workman, J.P. 1986. Range economics. Macmillan Publishing Company, New York. 